\title{
Karakterisasi Sifat Fisikokimia Pektin Kulit Jeruk Keprok Batu 55 (Citrus reticulata B), Jeruk Siam (Citrus nobilis var. microcarpa), Jeruk Manis Pacitan (Citrus sinensis L, Jeruk Nipis (Citrus aurantifolia swigle), dan Jeruk Lemon (Citrus limon $L$ ) yang Tumbuh di Kota Batu
}

\author{
Anis Febrianti Rahmanda K.W ${ }^{1 *}$, Sukardi ${ }^{1}$, Warkoyo ${ }^{1}$ \\ ${ }^{1}$ Program Studi Teknologi Pangan, Fakultas Pertanian Peternakan, Universitas Muhammadiyah \\ Malang, Malang, Indonesia \\ *Corresponding author email: anis_422021@webmail.umm.ac.id
}

\begin{abstract}
Utilization of orange peel waste in Batu City needs to be done to increase the selling power of consumers by extracting it as pectin. Pectin can be obtained using an extraction process. The stage of pectin extraction can affect the quality and quantity of the product. The extraction process will separate the pectin from the fruit tissue. This research was conducted with the production of orange peel flour as a material preparation process. The oranges used in this study were Batu 55 mandarin oranges (Citrus reticulata B), siam oranges (Citrus nobilis var. microcarpa), pacitan sweet oranges (Citrus sinensis L), lime (Citrus aurantifolia swigle), and lemons (Citrus limon L) which grows in the city of Batu. The next step was extraction using hydrochloric acid which was carried out using a nonfactorial randomized block design. The parameters observed were pectin yield, equivalent weight, methoxyl content, galacturonic acid content, esterification degree, moisture content, ash content, viscosity, colour intensity, and gel strength. The results showed that citrus peel varieties significantly affected yield, equivalent weight, galacturonic acid levels, degree of esterification, viscosity, and gel strength. Pectin with the best treatment based on the International Pectin Producers Association (IPPA) approach was shown in the Pacitan sweet orange peel variety with a galacturonic acid level of $99.15 \%$, a viscosity of $88.06 \mathrm{cP}$, gel strength of $2.289 \mathrm{~N}$, and an equivalent weight of 90.11 and resulted in yields. the most with a value of $24.20 \%$. The pectin produced in this study is classified as high methoxyl pectin.
\end{abstract}

Keywords: orange peel varieties, pectin, physicochemical properties

Abstrak. Pemanfaatan limbah kulit jeruk di Kota Batu perlu dilakukan untuk meningkatkan daya jual konsumen dengan mengekstraknya sebagai pektin. Pektin dapat diperoleh dengan cara proses ekstraksi. Tahapan ekstraksi pektin dapat mempengaruhi kualitas dan kuantitas produk. Proses ekstraksi akan memisahkan pektin dari jaringan buah. Penelitian ini dilakukan dengan pembuatan tepung kulit jeruk sebagai proses preparasi bahan. Jeruk yang digunakan pada penelitian ini adalah jeruk keprok batu 55 (Citrus reticulata B), jeruk siam (Citrus nobilis var. microcarpa), jeruk manis pacitan (Citrus sinensis L), jeruk nipis (Citrus aurantifolia swigle), dan jeruk lemon (Citrus limon L) yang tumbuh di kota Batu. Tahap selanjutnya adalah ekstraksi dengan menggunakan asam klorida yang dilakukan menggunakan rancangan acak kelompok non faktorial. Parameter yang diamati adalah rendemen pektin, berat ekivalen, kadar metoksil, kadar asam galakturonat, derajat esterifikasi, kadar air, kadar abu, intensitas warna, viskositas dan kekuatan gel. Hasil penelitian menunjukkan bahwa varietas kulit jeruk berpengaruh nyata 
terhadap rendemen, berat ekivalen, kadar asam galakturonat, derajat esterifikasi, viskositas dan kekuatan gel. Pektin dengan perlakuan terbaik berdasarkan pendekatan International Pectin Producers Association (IPPA) ditunjukkan pada varietas kulit jeruk manis pacitan dengan nilai kadar asam galakturonat 99,15\%, viskositas $88,06 \mathrm{cP}$, kekuatan gel 2,289 N, dan berat ekivalen 90,11 serta menghasilkan rendemen terbanyak dengan nilai $24,20 \%$. Pektin yang dihasilkan dalam penelitian ini tergolong dalam high methoxyl pectin.

Kata kunci : high methoxyl pectin, pektin, sifat fisikokimia,varietas kulit jeruk

\section{PENDAHULUAN}

Kota Batu merupakan salah satu daerah produsen jeruk yang produktifitasnya meningkat tiap tahun. Menurut Badan Pusat Statistik (2018) jeruk merupakan tanaman buah-buahan tahunan kedua terbesar di Kota Batu setelah apel yaitu sebesar 22.217,7 ton di tahun 2018 dan mengalami peningkatan sebesar tujuh persen ditahun 2019. Produktifitas yang meningkat ini tidak diimbangi dengan adanya pengolahan buah jeruk di Kota Batu. Selama ini buah jeruk hanya dimanfaatkan dengan cara dimakan langsung atau dijadikan sari buah saja. Pemanfaatan jeruk dikota Batu perlu dilakukan untuk meningkatkan daya jual konsumen dengan dilakukannya pengolahan sesuai karakteristik jeruk itu sendiri, salah satunya menjadikannya sebagai pektin. Sebuah penelitian menunjukkan bahwa jeruk menghasilkan rendemen pektin yang cukup tinggi yaitu 25-30 \% pada bagian kulit atau albedonya (Hariyati, 2006 dalam Kalonika, 2018).

Lapisan kulit luar jeruk memiliki ketebalan 1,8 mm hingga 6,2 $\mathrm{mm}$ tergantung jenis buah jeruk itu sendiri atau bisa dikatakan $30-35 \%$ bagian kulit buah jeruk dari keseluruhan jeruk (Izquerdo and Sendra, 2003 dalam Wachida, N. 2013 ). Potensi banyaknya limbah kulit jeruk yang dihasilkan di Indonesia diperkirakan sebesar 85.323, 49 ton berat kering (Kalonika, 2018). Industri pengolahan pektin komersial belum tersedia di Indonesia, karena itu Indonesia tercatat sebagai negara pengimpor pektin. Sementara kebutuhan pektin setiap tahun mengalami peningkatan, hal ini dapat dibuktikan dengan adanya nilai impor yang meningkat setiap tahunnya yaitu sekitar 10- $15 \%$ tiap tahun (Perina et al., 2007).

Tahun 2011 tercatat Indonesia mengimpor pektin sebanyak 100 ton untuk kebutuhan industri-industri Indonesia. Harga impor pektin yang mahal juga berdampak terhadap pengurangan devisa negara (BPS Sumut, 2011). Pemanfaatan kulit jeruk menjadi bahan baku pembuatan pektin menjadi salah satu cara potensi untuk manggulangi impor pektin yang saat ini dialami. Berdasarkan permasalahan diatas maka perlu dilakukan penelitian lebih lanjut mengenai ekstraksi pektin dari berbagai varietas jeruk yang tumbuh di Kota Batu. 


\section{METODE PENELITIAN}

\section{Bahan}

Bahan yang digunakan penelitian ini antara lain jeruk keprok batu 55 yang didapat dari petani di Desa Pendem, jeruk siam diperoleh dari petani di Desa Junrejo, jeruk manis pacitan didapat dari petani Desa Junggo, jeruk nipis dan jeruk lemon diperoleh dari petani Desa Gondorejo yang ada pada fase ripening, aquades, larutan $\mathrm{HCl} 0,2 \mathrm{~N}$, etanol 96\%, air, $\mathrm{NaCl}$, indikator fenolftalein, larutan $\mathrm{NaOH} 0,1 \mathrm{~N}$, larutan $\mathrm{NaOH}$ 0,2 N, Sukrosa, Asam sitrat $60 \%, \mathrm{CaCl}_{2}$, sodium sitrat $6 \%$.

Alat

Alat yang digunakan dalam penelitian ini diantaranya timbangan analitik, blender, pisau, kain saring, loyang, baskom, sendok, plastik, kompor, desikator, oven, tanur, pipet filler, beaker glass, erlenmeyer, buret, gelas corong, pipet ukur, gelas ukur, labu ukur, gelas pengaduk, aluminium foil, nampan, cabinet dryer, sarung tangan, masker, termometer, viskometer, $\mathrm{pH}$ meter, mesh 80, cawan porselen, waterbath, dan Texture analyzer.

\section{Desain Penelitian}

Rancangan yang digunakan pada penelitian ini adalah Rancangan Acak Kelompok Non Faktorial menggunakan 5 perlakuan dengan varietas jeruk yang tumbuh di Batu yaitu jeruk keprok Batu 55 (citrus reticulata B), jeruk siam (Citrus nobilis var. microcarpa), jeruk manis pacitan (Citrus sinensis L), jeruk nipis (Citrus aurantifolia swigle), dan jeruk lemon (Citrus Limon L) sebagai faktor dan dengan pengulangan sebanyak tiga kali, sehingga menghasilkan 15 unit perlakuan.

\section{Pembuatan Tepung Kulit Jeruk}

Preparasi bahan diawali dengan pencucian buah jeruk yang menggunakan air mengalir. Selanjutnya dilakukan pemisahan kulit jeruk dengan daging buahnya dengan cara pengupasan. Kemudian kulit jeruk dikecilkan ukurannya dengan menggunakan blender yang bertujuan untuk memperluas luas permukaan kulit jeruk. Setelah diblender kulit jeruk diayak menggunakan ayakan tepung. Berikutnya dilakukan pengeringan dengan pengering kabinet pada suhu $50^{\circ} \mathrm{C}$ hingga berat konstan. Setelah kulit jeruk kering dilakukan proses penghalusan menggunakan blender kemudian diayak untuk mendapatkan tepung kulit jeruk. Kulit jeruk yang tidak lolos ayakan dapat diblender kembali untuk memaksimalkan kuantitas tepung kulit jeruk yang dihasilkan (Widiastuti, 2015 dengan Modifikasi).

\section{Ekstraksi Pektin Kulit Jeruk}

Ekstraksi pektin kulit jeruk diawali dengan penimbangan tepung kulit jeruk sebanyak $30 \mathrm{~g}$ untuk setiap varietas. Kemudian ditambahkan larutan $\mathrm{HCl}$ $0,2 \mathrm{~N}$ sebanyak $900 \mathrm{~mL}$, dan diaduk. Setelah larutan homogen beaker glass 
ditutup menggunakan aluminum foil. Ekstraksi menggunakan water bath untuk suhu ekstraksi $80^{\circ} \mathrm{C}$ dengan waktu ekstraksi 120 menit. Setelah proses ekstraksi selesai, dilakukan proses pendinginan hingga suhu ruang. Selanjutnya dilakukan proses penyaringan sehingga terpisah antara ampas dan filtratnya. Pada tahap ini bagian yang diambil adalah filtrat untuk diproses lebih lanjut. Filtrat kemudian ditambahkan dengan etanol (96\%) dengan perbandingan 1:1 dan diendapkan selam 24 jam dengan ditutup menggunakan alumunium foil. Endapan yang terbentuk disaring menggunakan kain saring, kemudian endapan dicuci menggunakan etanol (96\%) sebanyak dua kali. Endapan yang dihasilkan disebut pektin basah kemudian dikeringkan menggunakan pengering cabinet selama 5 jam dengan suhu $50^{\circ} \mathrm{C}$ sampai pektin kering. Selanjutnya pectin dihaluskan menggunakan blender (Widiastuti, 2015 dengan Modifikasi).

\section{Parameter Penelitian}

Sifat fisikokimia pektin dari berbagai varietas jeruk meliputi rendemen pektin (Rosalina, dkk. 2017), berat ekivalen (Latupeirissa, dkk. 2019), kadar metoksil (Latupeirissa, dkk. 2019), kadar asam galakturonat (Latupeirissa, dkk. 2019), derajat esterifikasi (Latupeirissa, dkk. 2019), kadar air (Latupeirissa, dkk. 2019), kadar abu (Latupeirissa, dkk. 2019), nilai intensitas warna (Wachida, 2013), viskositas (Wachida, 2013) dan kekuatan gel (Wachida, 2013). Penentuan perlakuan terbaik berdasarkan standar IPPA (International Pectin Producers Assotion).

\section{Analisa Data}

Data yang diperoleh selanjutnya dianalisa dengan menggunakan analisis statistik atau ANOVA (Analysis of Variance) pada tingkat kepercayaan a $=5 \%$ untuk mengetahui perlakuan memberikan pengaruh nyata terhadap sifat fisikokimia pektin. Apabila hasil uji ANOVA menunjukkan F hitung lebih besar daripada $\mathrm{F}$ tabel pada taraf $5 \%$ maka, faktor memberikan pengaruh nyata terhadap parameterparameter penelitian yang dilakukan sehingga dilanjutkan dengan uji BNJ (Beda Nyata Jujur) pada $\alpha=5 \%$.

\section{HASIL DAN PEMBAHASAN \\ Rendemen Pektin}

Berdasarkan hasil analisis ragam menunjukkan bahwa terdapat pengaruh sangat nyata pada perlakuan beda varietas terhadap rendemen pektin yang dihasilkan. Perolehan data rendemen pektin ditampilkan dalam Tabel 1. 
Tabel 1. Rerata Rendemen Pektin Akibat Perbedaan Varietas Kulit Jeruk

\begin{tabular}{lc}
\hline \multicolumn{1}{c}{ Jenis Jeruk } & Nilai Rendemen (\%) \\
\hline Jeruk Keprok Batu 55 & $13,86^{\mathrm{a}}$ \\
Jeruk Siam & $14,26^{\mathrm{ab}}$ \\
Jeruk Manis Pacitan & $24,20^{\mathrm{c}}$ \\
Jeruk Nipis & $12,61^{\mathrm{a}}$ \\
Jeruk Lemon & $17,13^{\mathrm{b}}$ \\
\hline BNJ 5\%= & 5,730 \\
\hline
\end{tabular}

Keterangan : angka-angka yang diikuti oleh huruf yang sama menunjukkan tidak berbeda nyata pada uji $\mathrm{BNJ} \alpha=5 \%$

Hasil analisa yang tercantum pada Tabel 1 menunjukkan bahwa rendemen yang diperoleh adalah antara 12,61\% hingga 24,20\%. Hasil Rendemen pektin dapat dilihat pada Tabel 1 dimana hasilnya berbeda-beda pada setiap varietas. Literatur menyebutkan bahwa rendemen pektin yang diperoleh dari ekstraksi jeruk siam adalah 14,67\% ( Budiyanto, 2008) sedangkan pada penelitian ini menghasilkan rendemen pektin jeruk siam 14,26\%. Perbedaan tersebut terjadi karena perbedaan waktu ekstraksi yang dilakukan. Penelitian Budiyanto (2008) menggunakan waktu ekstraksi selama 80 menit sedangkan waktu ekstraksi pada penelitian ini adalah 120 menit. Rendemen pektin dari kulit jeruk nipis menurut Yadav (2017) adalah 23\% yang diekstraksi selama 15 menit, sedangkan rendemen pektin jeruk nipis pada penelitian ini adalah $12,61 \%$ dengan proses esktraksi 120 menit. Menurut Twinomuhwezi (2020) rendemen pektin kulit jeruk keprok diperoleh sebesar 15,23\% dengan waktu ekstraksi 60 menit, sedangkan dapa penelitian ini didapatkan hasil $13,86 \%$. Pektin yang terekstraksi terlalu lama akan berubah menjadi mineral sehingga rendemennya menjadi turun (Tampubolon, 2010). Rendemen pektin dari varietas jeruk lemon dan kulit jeruk manis yang diperoleh lebih besar daripada penelitian sebelumnya. Kulit jeruk lemon menghasilkan rendemen pektin $15 \%$ berdasarkan penelitian Meilina (2007), sedangkan pada penelitian ini rendemen pektin kulit jeruk lemon adalah $17,13 \%$. Rendemen pektin dari kulit jeruk manis menurut Wachida (2013) adalah $22,85 \%$, rendemen pektin dari kulit jeruk manis pada penelitian ini adalah $24,20 \%$.

Hasil analisis rendemen pektin pada penelitian ini paling tinggi diperoleh pada varietas jeruk manis pacitan yaitu sebesar $24,20 \%$. Hasil ini lebih baik jika dibandingkan dengan penelitian Damanik dan Pandia (2019) yang menghasilkan rendemen pektin paling tinggi dari kulit jeruk sebesar 20,12\%. Penelitian Rosalina, dkk (2017) menghasilkan rendemen pektin kulit jeruk kalamansi lebih rendah daripada penelitian ini yaitu sebesar 15,3\%. Zanella dan Taranto (2021) mendapatkan rendemen pektin lebih tinggi daripada penelitian ini yaitu sebesar antara 20,28\% - 38,21\% yang diperoleh dengan ekstraksi pektin dari albedeo dan flavedo jeruk manis Pera. 


\section{Berat Ekivalen}

Berdasarkan hasil analisis ragam menunjukkan bahwa terdapat pengaruh sangat nyata pada perlakuan beda varietas terhadap berat ekivalen pektin yang dihasilkan. Perolehan data berat ekivalen pektin ditampilkan dalam Tabel 2.

Tabel 2. Rerata Berat Ekivalen Pektin Akibat Perbedaan Varietas Kulit Jeruk

\begin{tabular}{lc}
\hline \multicolumn{1}{c}{ Jenis Jeruk } & Berat Ekivalen \\
\hline Jeruk Keprok Batu 55 & $1077,20^{\mathrm{c}}$ \\
Jeruk Siam & $711,75^{\mathrm{a}}$ \\
Jeruk Manis Pacitan & $896,35^{\mathrm{b}}$ \\
Jeruk Nipis & $766,79^{\mathrm{a}}$ \\
Jeruk Lemon & $889,57^{\mathrm{b}}$ \\
\hline BNJ 5\% & 96,192 \\
\hline
\end{tabular}

Keterangan : angka-angka yang diikuti oleh huruf yang sama menunjukkan tidak berbeda nyata pada uji $\mathrm{BNJ} \alpha=5 \%$

Hasil analisa berat ekivalen pektin berdasarkan Tabel 2 diperoleh bahwa pektin yang dihasilkan memiliki nilai berat ekivalen antara 711,75 hingga 1077,20 . Berat ekivalen pektin pada penelitian ini sedikit lebih besar dari batas maksimal yang ditetapkan oleh IPPA, yaitu batas berat ekivalen antara 600-800. Penelitian ini serupa dengan yang dilakukan oleh Meilina dan Sailah (2013) pada ekstraksi pektin dari kulit jeruk lemon yang menghasilkan nilai berat ekivalen sebesar 2129,95 serta penelitian Latupeirissa, dkk. (2019) pada proses ekstraksi pektin kulit jeruk manis kisar yang memperoleh nilai berat ekivalen sebesar 2011,6. Pelarut asam yang masih tersisa pada pektin mengakibatkan berat ekivalen semakin tinggi sehingga perlu dilakukan proses purifikasi lanjutan (Kolanika, 2018). Menurut Latupeirissa, dkk. (2019) berat ekivalen erat hubungannya dengan kekentalan pektin yang akan dihasilkan. Berat ekivalen adalah ukuran kandungan asam galakturonat yang tidak teresterifikasi atau sering disebut dengan dengan asam galakturonat bebas dalam rantai molekul pektin (Harini, 2010 dalam Wachida 2013). Menurut Fitria (2013) bobot molekul pektin tergantung pada jenis tanaman, kualitas bahan baku, metode ekstraksi dan perlakuan pada proes ekstraksi.

Nilai berat ekivalen pada penitian ini lebih tinggi daripada penelitian terdahulu. Menurut Twinomuhwedi (2020), berat ekivalen pektin dari kulit jeruk keprok adalah 111,56 dan berat ekivalen pektin kulit jeruk siam berdasarkan hasil penelitian Budiyanto and Yullianingsih, (2008) senilai 548,07. Pektin kulit jeruk nipis memperoleh nilai berat ekivalen sebesar 634,17 (Yadav, 2017). Hal ini diduga karena pada penelian ini jeruk yang digunakan telah mengalami proses pemasakan yang berlebihan. 


\section{Kadar Metoksil}

Berdasarkan hasil analisis ragam menunjukkan bahwa terdapat pengaruh tidak nyata pada perlakuan beda varietas terhadap kadar metoksil pektin yang dihasilkan. Perolehan data kadar metoksil pektin ditampilkan dalam Tabel 3.

Tabel 3. Rerata Kadar Metoksil Pektin Akibat Perbedaan Varietas Kulit Jeruk

\begin{tabular}{lc}
\hline \multicolumn{1}{c}{ Jenis Jeruk } & Kadar Metoksil (\%) \\
\hline Jeruk Keprok Batu 55 & $11,58^{\mathrm{a}}$ \\
Jeruk Siam & $11,23^{\mathrm{a}}$ \\
Jeruk Manis Pacitan & $12,47^{\mathrm{a}}$ \\
Jeruk Nipis & $11,97^{\mathrm{a}}$ \\
Jeruk Lemon & $12,07^{\mathrm{a}}$ \\
\hline BNJ 5\% $=$ & 1,797 \\
\hline
\end{tabular}

Keterangan : angka-angka yang diikuti oleh huruf yang sama menunjukkan tidak berbeda nyata pada uji BNJ $\alpha=5 \%$

Berdasarkan hasil rerata kadar metoksil pada Tabel 3 dapat diketahui bahwa kandungan kadar metoksil dari varietas jeruk antara $11,23 \%$ hingga 12,47\%. Pektin jeruk pada penelitian ini tergolong High Methoxyl Pectin, yaitu pektin dengan kandungan kadar metoksil lebih dari 7\%. Hasil ini dapat dilihat pada Tabel 3. Kadar metoksil pada penelitian ini termasuk terlalu tinggi dari standar IPPA, maka pektin harus melalui proses demetilasi untuk diproses selanjutnya (Prasetyowati, 2009 dalam Fitria, 2013). Proses demetilasi dilakukan dengan penggunaan asam dengan $\mathrm{pH}$ yang rendah yaitu $\pm 2,3$, karena adanya ion $\mathrm{H}^{+}$dari asam (aseton/ etanol) ikatan glikosidik dari gugus metil ester akan terputus yang mengahsilkan asam galakturonat. Selain itu demetilasi juga dapat terjadi karena aktifitas enzim pektin metil esterase yang dihasilkan oleh mikroorganisme atau yang secara alami ada pada tanaman tingkat tinggi (Voragen et al., 1995 dalam Wachida, N. 2013). Kadar metoksil pektin akan menentukan sifat fungsional larutan pektin dan dapat mempengaruhi struktur dan tekstur pembentukan gel (Latupeirissa dkk., 2019).

Kadar metoksil pektin dari kulit jeruk siam berdasarkan literatur terdahulu adalah 6,34\% (Budiyanto, 2008) hal ini menunjukkan bahwa penelitian ini menghasilkan kadar metoksil yang lebih tinggi daripada literatur yaitu sebesar 11,23\%. Literatur lain menyebutkan bahwa pektin dari kulit jeruk manis memiliki kadar metoksil sebesar 6,62\%, sedangkan penelitian ini menghasilkan kadar metoksil senilai 12,47\%. Nilai kadar metoksil kulit jeruk nipis adalah 8,23\% Yadav, dkk. (2018) dan kadar metoksil pektin kulit jeruk lemon menurut Meilina dan Sailah (2013) adalah 6,05\%. Kadar metoksil yang lebih tinggi ini disebabkan karena waktu ekstraksi pada penelitian ini lebih panjang daripada penelitian 
terdahulu. Waktu yang digunakan pada penelitian terdahulu lebih singkat dariapada penelitian ini yaitu 45- 80 menit. Kadar metoksil pektin akan semakin besar dengan meningkatnya waktu ekstraksi. Penelitian Twinomuhedi (2020) menghasilkan nilai kadar metoksil yang sama yaitu penelitian mengenai pektin dari kulit jeruk dengan nilai kadar metoksil sebesar 15,75\%. Hasil kadar metoksil pada penelitian ini lebih tinggi jika dibandingkan dengan penelitian Damonik dan Pandis (2019) yang memperoleh hasil kadar metoksil sebesar 10,54\% dari ekstraksi pektin kulit jeruk.

\section{Kadar Asam Galakturonat}

Berdasarkan hasil analisis ragam menunjukkan bahwa terdapat pengaruh sangat nyata pada perlakuan beda varietas terhadap kadar asam galakturonat pektin yang dihasilkan. Perolehan data kadar asam galakturonat pektin ditampilkan dalam Tabel 4.

Tabel 4. Rerata Kadar Asam Galakturonat Pektin Akibat Perbedaan Varietas Kulit Jeruk

\begin{tabular}{lc}
\hline \multicolumn{1}{c}{ Jenis Jeruk } & Kadar Asam Galakturonat (\%) \\
\hline Jeruk Keprok Batu 55 & $64,52^{\mathrm{a}}$ \\
Jeruk Siam & $78,56^{\mathrm{b}}$ \\
Jeruk Manis Pacitan & $99,15^{\mathrm{c}}$ \\
Jeruk Nipis & $91,85^{\mathrm{c}}$ \\
Jeruk Lemon & $79,17^{\mathrm{b}}$ \\
\hline BNJ 5\%= & 9,815 \\
\hline
\end{tabular}

Keterangan : angka-angka yang diikuti oleh huruf yang sama menunjukkan tidak berbeda nyata pada uji $\mathrm{BNJ} \alpha=5 \%$

Berdasarkan hasil analisa Tabel 4 diperoleh kadar asam galakturonat antara 64,52 hingga 99,15\%. Pektin dari ekstraksi kulit jeruk manis pacitan memiliki kadar asam galakturonat tertinggi (Tabel 4) artinya pektin yang dihasilkan memiliki kemurnian yang tinggi, dimana semakin tinggi kadar galakturonat, nilai pengotornya semakin sedikit. Pektin merupakan salah satu bahan yang berfungsi sebagai gelling agent. Semakin besar kandungan asam galakturonat maka semakin tinggi kemurnian pektin sehingga gel yang dihasilkan juga semakin baik (Latupeirissa dkk., 2019). karena semakin kecil kandungan senyawa organik seperti D-galaktosa, L-arabinosa, dan L-ramnosa atau gula jenis lain (Rosalina Y., dkk., 2017). Senyawa tersebut dapat terbawa pada waktu proses penggumpalan pektin, dan dapat dihilangkan melalui pelarutan kembali pektin dalam air dan penggumpalan, namun hanya dapat menghilangkan sebagian. Secara keseluruhan pektin yang dihasilkan sudah memenuhi standar mutu IPPA (2012) yang menyatakan bahwa pektin harus memiliki kadar asam galakturonat minimal 35\%. 
Menurut Wachida (2013), kadar asam galakturonat pektin kulit jeruk manis mencapai 80,90\%, sedangkan pada penelitian ini adalah 99,15\%. Latupeirissa dkk. (2019) menghasilkan pektin kulit jeruk manis kisar dengan kadar asam galakturonal sebesar 41,64\&. Literatur lain menyebutkan kadar asam galakturonat pektin kulit jeruk siam adalah 65,18\% (Budiyanto, 2008), hasil tersebut lebih rendah daripada penelitian ini yang memperoleh nilai kadar asam galakturonat sebesar $78,56 \%$. Sebuah literatur yang mempelajari tentang pektin dari kulit jeruk nipis mendapatkan hasil kadar asam galakturonat sebesar 67,76\% namun, hasil penelitian ini menunjukkan bahwa kadar asam galakturonat dari pektin kulit jeruk nipis sebsar 91, 85\%. Penelitian kulit jeruk lemon juga memperoleh hasil yang serupa dimana hasil kadar asam galakturonat penelitian ini lebih tinggi daripada penelitian terdahulu yaitu 48,61\% (Meilina \& Sailah, 2013). Hasil perolehan kadar asam galakturonat pada penelitian ini memiliki hasil yang lebih tinggi jika dibandingakn dengan kadar asam galakturonat dari kulit jeruk kalamansi yang diperoleh Rosalina, dkk., (2017) yaitu sebesar 93,51. Penelitian Zanella \& Taranto memperoleh hasil kadar asam galakturonat yang lebih rendah dari penelitian ini yaitu $93,636 \%$ untuk pektin dari albedo jeruk manis pera, dan 93,291 untuk flavedo jeruk manis pera.

\section{Derajat Esterifikasi}

Berdasarkan hasil analisis ragam menunjukkan bahwa terdapat pengaruh sangat nyata pada perlakuan beda varietas terhadap derajat esterifikasi pektin yang dihasilkan. Perolehan data derajat esterifikasi pektin ditampilkan dalam Tabel 5.

Tabel 5. Rerata Derajat Esterifikasi Pektin Akibat Perbedaan Varietas Kulit Jeruk

\begin{tabular}{lc}
\hline \multicolumn{1}{c}{ Jenis Jeruk } & Derajat Esterifikasi (\%) \\
\hline Jeruk Keprok Batu 55 & $102,43^{\mathrm{d}}$ \\
Jeruk Siam & $64,39^{\mathrm{a}}$ \\
Jeruk Manis Pacitan & $90,11^{\mathrm{cd}}$ \\
Jeruk Nipis & $73,90^{\mathrm{ab}}$ \\
Jeruk Lemon & $86,60^{\mathrm{bc}}$ \\
\hline BNJ 5\% $=$ & 14,533 \\
\hline
\end{tabular}

Keterangan : angka-angka yang diikuti oleh huruf yang sama menunjukkan tidak berbeda nyata pada uji BNJ $\alpha=5 \%$

Derajat esterifikasi pektin kulit jeruk berdasarkan hasil analisa tersaji pada Tabel 5 yang mana dapat diperoleh derajat esterifikasi antara 64,39 hingga 102,43\%. Berdasarkan Tabel 5 secara umum pektin jeruk yang dihasilkan pada penelitian ini adalah pektin bermetoksil tinggi, yaitu pektin dengan derajat esterifikasi lebih dari 50\%. Tingginya nilai derajat esterifikasi ini berarti banyaknya gugus metil ester yang berikatan pada ikatan glikosidik. Jumlah gugus metil ester menunjukkan jumlah gugus karboksil yang tidak teresterifikasi. 
Semakin tinggi derajat esterifikasi maka semakin rendah gugus karboksil pada struktur pektin. (Megawati dan Elfi, 2016). Apabila ekstraksi dilakukan terlalu lama maka pectin akan berubah menjadi asam pektat yang mana asam galakturonatnya bebas dari gugus metil ester. Jumlah gugus metil ester menunjukkan jumlah gugus karboksil tidak teresterifikasi (Fitria, 2013).

Menurut literatur derajat esterifikasi kulit jeruk keprok adalah 85,016\% (Twinomuhwedi, 2020), sedangkan hasil esterifikasi pada penelitian ini lebih tinggi yaitu 102,43. Penelitian serupa dihasilkan pada pektin kulit jeruk siam dengan nilai derajat esterifikasi lebih besar dari literatur dimana derajat esterifikasi pektin pada literatur sebesar 61,10\% (Budiyanto, 2008), sedangkan pada penelitian ini derajat esterifikasi didapatkan nilai 64,39\%. Literatur derajat esterifikasi pektin kulit jeruk nipis adalah 57,17\%, sedangkan dalam penelitian ini didapatkan hasil derajat esterifikasi senilai 73,90\%. Waktu ekstraksi pada penelitian terdahulu berkisar antara 45 menit hingga 80 menit, sedangkan waktu yang digunakan dalam penelitian ini adalah 120 menit. Tingginya nilai derajat esterifikasi ini berarti banyaknya gugus metil ester yang berikatan pada ikatan glikosidik. Jumlah gugus metil ester menunjukkan jumlah gugus karboksil yang tidak teresterifikasi.

\section{Kadar Air}

Berdasarkan hasil analisis ragam menunjukkan bahwa terdapat pengaruh tidak nyata pada perlakuan beda varietas terhadap kadar air pektin yang dihasilkan. Perolehan data kadar air pektin ditampilkan dalam Tabel 6.

Tabel 6. Rerata Kadar Air Pektin Akibat Perbedaan Varietas Kulit Jeruk

\begin{tabular}{lc}
\hline \multicolumn{1}{c}{ Jenis Jeruk } & Kadar Air (\%) \\
\hline Jeruk Keprok Batu 55 & $11,63^{\mathrm{a}}$ \\
Jeruk Siam & $10,44^{\mathrm{a}}$ \\
Jeruk Manis Pacitan & $10,97^{\mathrm{a}}$ \\
Jeruk Nipis & $09,75^{\mathrm{a}}$ \\
Jeruk Lemon & $10,81^{\mathrm{a}}$ \\
\hline BNJ 5\% = & 2,208 \\
\hline
\end{tabular}

Keterangan : angka angka yang diikuti oleh huruf yang sama menunjukkan tidak berbeda nyata pada uji $\mathrm{BNJ} \alpha=5 \%$

Kadar air menyatakan kandungan air yang berada di dalam bahan. Hasil rerata kadar air pektin diperoleh antara 09,75 hingga 11,63\%. Pada Tabel 6 dapat diketahui bahwa pektin dari varietas jeruk nipis menghasilkan kadar air paling rendah yaitu 09,75\%. Kadar air paling tinggi dihasilkan oleh ekstraksi pektin dengan varietas jeruk keprok batu 55. Hal ini dikarenakan kadar air awal kulit jeruk kering yang berbeda- beda. Menurut Balitjestro (2016) kulit jeruk keprok batu 55 memiliki kadar air 11,82\% pada basis kering, sedangkan kadar air kulit jeruk nipis basis kering sejumlah 11,53 \% (Merve, K., et al. 2014). Semakin tinggi 
kadar air awal bahan, maka kadar air pektin yang dihasilkan juga akan semakin tinggi. Kadar air pektin lebh banyak dpengaruhi oleh derajat pengeringan endapan pektin dan kondisi penyimpanannya (Meilina dan Sailah, 2013). Pada penelitian kali ini menghasilkan pektin dengan kadar air kurang dari $12 \%$. Hasil ini sudah memenuhi standar mutu yang ditetapkan oleh International Pectin Producers Association (2012) yang menyebutkan kadar air pektin maksimal adalah $12 \%$.

\section{Kadar Abu}

Berdasarkan hasil analisis ragam menunjukkan bahwa terdapat pengaruh tidak nyata pada perlakuan beda varietas terhadap kadar abu pektin yang dihasilkan. Perolehan data kadar abu pektin ditampilkan dalam Tabel 7.

Tabel 7. Rerata Kadar Abu Pektin Akibat Perbedaan Varietas Kulit Jeruk

\begin{tabular}{lc}
\multicolumn{1}{c}{ Jenis Jeruk } & Kadar Abu (\%) \\
\hline Jeruk Keprok Batu 55 & $0,67^{\mathrm{a}}$ \\
Jeruk Siam & $0,60^{\mathrm{a}}$ \\
Jeruk Manis Pacitan & $0,65^{\mathrm{a}}$ \\
Jeruk Nipis & $0,52^{\mathrm{a}}$ \\
Jeruk Lemon & $0,55^{\mathrm{a}}$ \\
\hline BNJ 5\% = & 0,171 \\
\hline \multicolumn{2}{c}{ Keterangan : angka-angka yang diikuti oleh huruf yang sama menunjukkan tidak } \\
\multicolumn{2}{c}{ berbeda nyata pada uji BNJ $\mathrm{a}=5 \%$}
\end{tabular}

Hasil dari pengukuran yang tersaji pada Tabel 7 menghasilkan kadar abu sebesar 0,55 hingga $0,67 \%$. Nilai kadar abu diperoleh pada saat proses ekstraksi pektin terjadi reaksi hidrolisis protopektin sehingga dapat mineral-mineral bertambah seperti kalsium dan magnesium didalam pektin yang mengendap. Adanya asam dapat melarutkan mineral alami dari bahan yang diekstrak. Mineral tersebut akan turut mengendam bercampur dengan pektin pada saat proses pengendapan (Rosalina Y., dkk., 2017). Menurut Balitjestro, (2016) kulit jeruk keprok batu 55 memiliki kadar abu 6,26\% pada basis kering, sedangkan kadar air kulit jeruk nipis basis kering sejumlah 4,19\% (Merve, K., et al. 2014).. Semakin banyak kadar abu di awal bahan akan menghasilkan kadar abu pektin juga semakin tinggi, selain itu kematangan buah juga menjadi faktor tingginya kadar abu, dimana seiring meningkatnya kematangan buah $(\mathrm{pH})$ yang digunakan (Rosalina Y., dkk., 2017). Secara keseluruhan kadar abu yang dihasilkan pada Tabel 1 sudah memenuhi batas maksimal kadar abu yang ditetapkan oleh IPPA (2012), yaitu sebesar 10\%. Proses pencucian endapan pektin yang tidak maksimal akan menyebabkan banyaknya zat pengotor yang tersisa didalam pektin. Hal ini mengakibatkan kadar abu pektin akan tinggi. 


\section{Nilai Intensitas Warna}

Berdasarkan hasil analisis ragam menunjukkan bahwa terdapat pengaruh tidak nyata pada perlakuan beda varietas terhadap intensitas warna pektin yang dihasilkan. Perolehan data nilai intensitas warna ditampilkan dalam Gambar 1.

\section{Intensitas Warna}

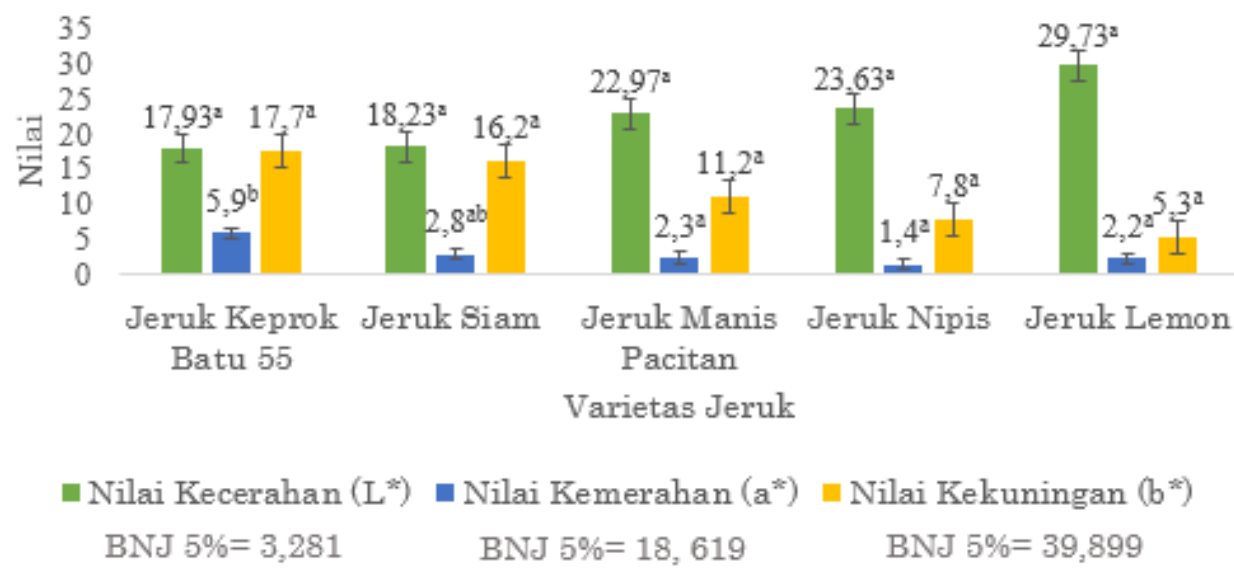

Gambar 1 Histogram Rerata Nilai Intensitas Warna Pektin Akibat Perbedaan Varietas Kulit Jeruk

Hasil analisa rerata warna pektin kulit jeruk dengan perbedaan varietas memiliki tingkat kecerahan warna senilai 17,93 hingga 29,73 sesuai dengan Gambar 1. Nilai rerata derajat kekuningan pektin dari kulit jeruk dengan berbeda varietas antara 5,3 hingga 17,7. Perbedaan tingkat kecerahan pektin dapat dilihat pada Gambar 1 yang berhubungan dengan keberadaan pigmen yang berbeda-beda pada bahan baku kulit jeruk. Dimana selama ekstraksi pigmen tersebut ikut terekstrak kedalam pektin. Proses pematangan akan merubah warna pada kulit jeruk yang disebabkan oleh adanya degradasi pigmen. Tetapi tiap varietas mengalami degradasi pigmen yang berbeda-beda, sehingga setelah dilakukan proses ekstraksi pektin yang dihasilkan memiliki nilai kecerahan yang berbeda. Kualitas dan kuantitas pektin yang dihasilkan tergantung pada kualitas dan kuantitas bahan baku yang digunakan. Dengan penggunaan bahan baku yang berbeda akan menghasilkan kualitas pektin yang berbeda pula (Harini, 2010 dalam Wachida, N. 2013). Kandungan gula yang ada pada varietas jeruk juga mempengaruhi tingkat kecerahan. Semakin rendah kandungan gula maka pektin yang dihasilkan akan semajub cerah. Penggunaan etanol sebagai pengendap juga berperan melarutkan earna pada saat proses pencucian. Ethanol dapat melepaskan bahan asing (mineral) dan zat warna pada proses pencucian (Wurzburg, 1995 dalam Wachida, N. 2013). Proses pencucian yang maksimal dapat meningkatkan kecerahan pektin yang dihasilkan. 
Rerata derajat kemerahan ( $\mathrm{a}^{*}$ ) berkisar antara 1,4 hingga 5,9. Pektin kulit jeruk keprok batu 55 memiliki warna yang cenderung merah daripada pektin dari kulit jeruk dari varietas lain. Adanya warna kemerahan pada kulit buah jeruk dihasilkan adanya perombakan kloroplas fotosintesis menjadi karotenoid pada kromoplas. Perubahan pigmen yang terjadi tiap vaietas mengalami perbedaan sehingga setelah dilakukan proses ekstraksi pektin yang dihasilkan memiliki kecerahan yang berbeda. Warna kuning pada pektin disebabkan karena adanya pengaruh pengeringan. Umumnya bahan pangan yang dikeringkan berubah warna kecoklatan (Apandi, 1984 dalam Wachida, N. 2013). Proses pencoklatan bisa terjadi karena reaksi enzimatis atau non-enzimatis. Pencoklatan karena reaksi enzimatis disebabkan enzim fenolase bereaksi dengan oksigen dan udara sehingga mengubah fenolik menjadi metanin yang berwarna coklat. Pencoklatan akibat non-enzimatis merupakan perubahan warna karena pengolahan akibat panas dengan reaksi yang terjadi yaitu reaksi karamelisasi dan maillard.

\section{Viskositas}

Berdasarkan hasil analisis ragam menunjukkan bahwa terdapat pengaruh nyata pada perlakuan beda varietas terhadap viskositas pektin yang dihasilkan. Perolehan data viskositas pektin ditampilkan dalam Tabel 8.

Tabel 8 Rerata Nilai Viskositas Pektin Akibat Perbedaan Varietas Kulit Jeruk

\begin{tabular}{lc}
\multicolumn{1}{c}{ Jenis Jeruk } & Viskositas $(\mathrm{cP})$ \\
\hline Jeruk Keprok Batu 55 & $25,28^{\mathrm{a}}$ \\
Jeruk Siam & $42,78^{\mathrm{ab}}$ \\
Jeruk Manis Pacitan & $88,06^{\mathrm{b}}$ \\
Jeruk Nipis & $71,11^{\mathrm{b}}$ \\
Jeruk Lemon & $55,00^{\mathrm{ab}}$ \\
\hline BNJ 5\% = & 47,507 \\
\hline \multicolumn{2}{|c|}{ Keterangan : angka-angka yang diikuti oleh huruf yang sama menunjukkan tidak } \\
\multicolumn{2}{c}{ berbeda nyata pada uji BNJ $\alpha=5 \%$}
\end{tabular}

Berdasarkan hasil analisa pada Tabel 8 menunjukkan bahwa viskositas pektin dihasilkan antara 25,28 $\mathrm{cP}$ hingga 88,06 $\mathrm{cP}$. Hasil analisa viskositas menurut Tabel 8 tergolong pada viskositas yang rendah, penelitian ini serupa dengan penelitian Wulandari, dkk. (2018) yang menghasilkan viskositas pektin sebesar 40,5 $\pm 1,73 \mathrm{cP}$. Viskositas yang rendah ini dikarenakan adanya proses depolimerisasi. Proses depolimesisasi dapat terjadi pada pektin akibat aktivitas peningkatan suhu dan waktu. Semakin besar proses depolimerisasi maka viskositas larutan pektin akan semakin kecil (Hariyati, 2006 dalam Wachida, N. 2013). Adanya senyawa pengotor seperti gula asam organik dan garam yang ikut terendapkan dapat mempengaruhi nilai viskositas pektin (Wulandari, dkk., 2018). Viskositas pektin perlu diketahui mengingat salah satu fungsi dari pektin sebagai 
pengental dan pembentuk tekstur. Sebelum gel terbentuk, senyawa tunggal pektin akan dikelilingi oleh molekul air. Apabila lingkungan dari molekul tersebut adalah larutan bersuasana asam, maka pektin akan kehilangan daya ikatnya dengan air dan akan berikatan membentuk gel yang baik. (Meilina dan Sailah (2013) mengatakan bahwa rendahnya berat molekul pektin mengakibatkan tingkat viskositas menjadi rendah.

Menurut Budiyanto (2008) nilai viskositas pektin kulit jeruk siam adalah 26,13 c.P, sedangkan viskositas pektin kulit jeruk lemon adalah 24,95 cP (Meilina\&Sailah, 2013). Nilai viskositas dari literatur lebih kecil daripada nilai viskositas dalam penelitian ini. Meilina \& Sailah (2013) mengatakan bahwa rendahnya berat molekul pektin mengakibatkan tingkat viskositas menjadi rendah. Proses depolimerisasi pektin juga mempengaruhi rendahnya nilai viskositas pada penelitian terdahulu (Harini, 2006 dalam Wachida 2013). Kemampuan pektin dalam membentuk gel dapat dilakukan dengan cara penambahan gula dan asam. Karakteristik kimia pektin juga mempengaruhi kemampuan pektin dalam pembentukan gel. Pektin yang memiliki kadar metoksil dan kadar galakturonat tinggi memiliki kemampuan dalam pembentukan gel dengan baik (Wachida, 2013).

\section{Kekuatan Gel}

Berdasarkan hasil analisis ragam menunjukkan bahwa terdapat pengaruh sangat nyata pada perlakuan beda varietas terhadap kekuatan gel pektin yang dihasilkan. Perolehan data kekuatan gel pektin ditampilkan dalam Tabel 9.

Tabel 9 Rerata Nilai Kekuatan Gel Pektin Akibat Perbedaan Varietas Kulit Jeruk

\begin{tabular}{lc}
\hline \multicolumn{1}{c}{ Jenis Jeruk } & Kekuatan Gel (N) \\
\hline Jeruk Keprok Batu 55 & $0,997^{\mathrm{a}}$ \\
Jeruk Siam & $1,053^{\mathrm{a}}$ \\
Jeruk Manis Pacitan & $2,289^{\mathrm{b}}$ \\
Jeruk Nipis & $1,222^{\mathrm{a}}$ \\
Jeruk Lemon & $1,205^{\mathrm{a}}$ \\
\hline BNJ 5\%= & 0,786 \\
\hline
\end{tabular}

Keterangan: angka-angka yang diikuti oleh huruf yang sama menunjukkan tidak berbeda nyata pada uji $\mathrm{BNJ} \alpha=5 \%$

Pengukuran nilai kekuatan gel berdasarkan Tabel 9 diperoleh 0,997 hingga 2,289 N. Perbedaan nilai kekuatan gel pada penelitian ini yang dapat dilihat pada Tabel 9. Pektin yang dihasilkan dari kulit jeruk manis menghasilkan nilai kekuatan gel paling tinggi yaitu sebesar 2,289 N. Kulit jeruk yang menghasilkan nilai kekuatan gel paling rendah adalah pektin dari kulit jeruk keprok batu 55 yaitu 0,997 N. Menurut Harini (2010 dalam Wachida 2013) perbedaan nilai kekuatan gel disebabkan karena senyawa kimia penyusun bahan baku berbeda, selain itu besar kecilnya kekuatan gel juga dipengaruhi juga oleh 
$\mathrm{pH}$, lama dan suhu pemasakan serta penambahan zat pembantu yaitu asam dan gula. Kekuatan gel pektin dengan karakteristik high metoksil pektin adalah 1,54 N (Harini 2010 dalam Wachida 2013). Namun penelitian lain menunjukkan bahwa nilai kekuatan gel pektin dari kulit jeruk lemon adalah 3,16 N (Meilina, 2007). Penelitian serupa memperoleh hasil kekuatan gel pektin kulit jeruk manis senilai 3,73 N (Wachida, 2013).

Mekanisme pembentukan pektin pada pektin tinggi metoksil menurut Chaplin (2004 dalam Wachida, N. 2013) adalah molekul pektin saling berikatan membentuk struktur tiga dimensi, dimana interaksi antara gugus karboksil yang tidak terdisosiasi dan gugus hidroksil pada ikatan hidrogen serta interaksi antara gugus hidrofob antara gugus metoksil. Pektin akan mengalami dehidrad dan muatan negatif akan tereduksi dan interaksi antar rantai-rantai terjadi. Tingkat kekuatan gel juga dipengaruhi oleh adanya air yang terkandung didalam pektin. Kandungan air bebas dalam pektin yang cenderung sedikit karena pektin akan menyerap air masuk kedalam struktur molekuln pektin (Suptijah, P., dkk. 2014).

\section{KESIMPULAN}

Varietas kulit jeruk mempengaruhi karakteristik fisikokimia pektin yang meliputi berat ekivalen, kadar asam galakturonat, derajat esterifikasi, viskositas, kekuatan gel dan rendemen antara 12,61\% hingga 24,20\% dari berbagai kulit jeruk yang tumbuh di Kota Batu. Pektin yang dihasilkan dalam penelitian ini tergolong High Metoxyl Pectin. Varietas terbaik berdasarkan pendekatan standar pektin yang dikelu arkan International Pectin Producers Association (IPPA) pada varietas kulit jeruk manis pacitan dengan nilai kadar asam galakturonat 99,15\%, viskositas 88,06 cP., kekuatan gel 2,289 N, rendemen 24,20 serta berat ekivalen 90,11 .

\section{DAFTAR PUSTAKA}

Ana, U. M. \& Hapsari, T. P, 2018. Pengaruh Penambahan Pektin Kulit Jeruk Dan Sukrosa Terhadap Karakteristik Fisikokimia dan Organoleptik Selai Jahe (Zingiber officinale). Teknologi Pangan: Media Informasi dan Komunikasi Ilmiah Teknologi Pertanian, 9(2), pp. 132-139. DOI: https://doi.org/10.35891/tp.v9i2.1192

[Balitjestro] Balai Penelitian Tanaman Jeruk Dan Buah Subtropis. Tips Membedakan Jenis Jeruk. [diakses pada 15 Juli 2020]. Tersedia dari: http://balitjestro.litbang.pertanian.go.id/tips-membedakan-jenis-jeruk/).

[BPS] Badan Pusat Statistik. Badan Pusat Statistik Kota Batu Dalam Angka 2019. [diakses pada 18 April 2020]. Tersedia dari: (https://batukota.bps.go.id/publication/2018/08/16/0359f1ad025252a858315ad 1/kota-batu-dalam-angka-2018.html).

[IPPA] International Pectin Procedur Association. What Is Pectin?. [diakses pada 
21 September 2020]. Tersedia dari:

http://www.ippa.info/what is pectin.html.

Belen, G., Beatriz, G., Remedios, Y., Henk, S., \& Jose, L. A, 2016. Prebiotic Potential of Pectins and Pectic Oligosaccharides Derived From Lemon Peel Wastes and Sugar Beet Pulp: A Comparative Evaluation. Journal of Functional Foods, 20, pp. 108-121. DOI: https://doi.org/10.1016/j.jff.2015.10.029

Budiyanto, A., and Yullianingsih. 2008. Pengaruh Suhu Dan Ektraksi Terhadap Karakter Pektin Dari Ampas Jeruk Siam (Citrus nobilis L). Jurnal Penelitian Pasca Panen Pertanian, 5(2).

Colodel, C., Vriesmann, L. C., Teofilo, R. F., \& de Oliveria P. C. L, 2018. Extraction Of Pectin from Ponkan (Citrus reticulata Blanco cv. Ponkan) Peel: Optimization and Structural Characterization. International Journal of Biological Macromolecules, 117, pp.385-391. DOI: https://doi.org/10.1016/j.ijbiomac.2018.05.048

Damanik, D. A., \& Pandia, S., 2019. Ekstraksi Pektin dari Limbah Kulit Jeruk (Citrus sinensis) dengan Metode Ekstraksi Gelombang Ultrasonik Menggunakan Pelarut Asam Klorida (HCl). Jurnal Teknik Kimia USU, 08, pp.85-89. DOI: https://doi.org/10.32734jtk.v8i2.2036

Fitria, V. 2013. Karakterisasi Pektin Hasil Ekstraksi dari Limbah Kulit Pisang Kepok (Musa balbisiana ABB). Skripsi. Universitas Islam Negeri Syarif Hidayatullah.

Han, H. S \& Song, K. B, 2020. Antioxidant Activities of Mandarin (Citrus unshiu) Peel Pectin Films Containing Sage (Salvia officinalis) Leaf Extract. International Journal of Food Science \& Technology, 55, pp. 3173-3181. DOI: https://doi.org/10.1111/ijfs.14581

Hu, Y., Zhang, W., Ke Zunli, Li Yan \& Zhou, Z, 2017. In Vitro Release And Antioxidant Activity Of Satsuma Mandarin (Citrus reticulata Blanco cv. unshiu) Peel Flavonoids Encapsulated By Pectin Nanoparticles. International Journal of Food Science \& Technology, 52, pp. 2362-2373. DOI: https://doi.org/10.1111/ijfs. 13520

Kolanika, J. 2018. Optimasi Ekstrakasi Pektin Dari Kulit Jeruk Manis (Citrus sinensis) Dengan Metode Microwave Assisted Extraction (MAE) Terhadap Total Pektin Dan Tingkat Kecerahan Pektin. Skripsi. Universitas Brawijaya, Malang.

Latupeirissa, J., Eirene G., Fransina. Matheis F. J. D. P. Tanasale., \& Chudeya Y.B. 2019. Ekstraksi Dan Karakterisasi Pektin Kulit Jeruk Manis Kisar (Citrus Sp.). Indonesian Journal Chemical Res, 7(1), pp. 61-68. DOI: https://doi.org/10.30598//ijcr.2019.7-egf

Megawati \& Elfi L. M. 2016. Ekstraksi Pektin Dari Kulit Buah Pisang Kepok (Musa paradisiaca) Menggunakan Pelarut HCl Sebagai Edible Film." Jurnal Teknik Kimia, Universitas Sumatera Utana, 5(1). DOI: https://doi.org/10.15294/jbat.v5i1.4177

Meilina, H. \& I. Sailah. 2013. Produksi Pektin dari Kulit Lemon Citrus (Citrus medica). Prosidium Simposium Nasional Polimer $V$. Universitas Syah Kuala Darussalam, Banda Aceh. ISSN 1410-8720, pp. 117-126. 
Merve, K., Antonio, G. S., Marie-Jeanne, C., Susanne, O. S. \& Marie-Christine, R., 2014. Characterization of Citrus Pectin Samples Extracted Under Different Conditions: Influence of Acid Type and $\mathrm{pH}$ of Extraction. Annals of Botany, 114, pp. 1319-1326. DOI: https://doi.org/10.1093/aob/mcu150

Mohd Rasidek, N. A., Mariam, F. M. N., Koji, I., Norazah, A. R., Yuichiro, N \& Hideaki, T., 2018. Rheological flow models of banana peel pectin jellies as affected by sugar concentration. International Journal of Food Properties, 21, pp. 2087-2099. DOI: https://doi.org/10.1080/10942912.2018.1514505

Perina, Irene, Sutiruiani, Soetaredjo F. D, \& Hindarso, H. 2007. Ekstraksi Pektin Dari Berbagai Macam Kulit Jeruk. Jurnal Widya Teknik, 6, pp.1-10.

Pradhan, A., Sharma, L., Tiwari, A. \& Chettri, P., 2019. Characterization Of Pectin Extracted from Citrus reticulata L. Blanco Collected from Different Altitudes of Sikkim Himalaya. Journal of Applied and Natural Science, 11, pp. 168-181. DOI: https://doi.org/10.31018/jans.v11i1.1997

Priyadarshi, R., Kim, S.M and Rhim, J. W, 2021. Pectin/Pullulan Blend Films for Food Packaging: Effect Of Blending Ratio. Food Chemistry Journal, 347, pp. 129022. DOI: https://doi.org/10.1016/j.foodchem.2021.129022

Rivaz, B., Torrado, A., Torre, P., Converty, A., \& Dominguez, J. M. 2008. Submerged Citric Acid Fermentation on Orange Peel Autohydrolysate. Journal of Agricultural and Food Chemistry, 56(23), pp.80-87. DOI: https://doi.org/10.1021/jf073388r

Rosalina, Y., Susanti, L., \& Karo, S. B. 2017. Kajian Ekstraksi Pektin Dari Limbah Jeruk Rimau Gerga Lebong (Jeruk Rgl) dan Jeruk Kalamansi. Jurnal Agrointek, $\quad 11(2), \quad$ pp. 68-74. https://doi.org/10.21107/agrointek.v11i2.3174

Sri, R., Wara, D. P. R., Latifah \& Ella, K., 2016. Ekstraksi dan Karakterisasi Pektin Dari Belimbing Wuluh (Averrhoa bilimbi L). Jurnal Bahan Alam Terbarukan, 5, pp. 29-36. DOI: https://doi.org/10.15294/jbat.v4i2.5432

Sudaryati \& Jariyah, 2017. Karakteristik Fisikokimia Permen Jelly Buah Pedada (Soneratia caseolaris). Jurnal Teknologi Pangan, 11. DOI: https://doi.org/10.33005/jtp.v11i1.754

Suptijah, P., Sugung, H. S \& Cholil, A., 2014. Analisis Kekuatan Gel (Gel Strength) Produk Permen Jelly Dari Gelatin Kulit Ikan Cucut Dengan Penambahan Karaginan dan Rumput Laut. Jurnal Pengolahan Hasil Perikanan Indonesia, 6. DOI: https://doi.org/10.17844/jphpi.v16i2.8053

Twinomuhwezi H., Awuchi C. G., \& Daphine K. 2020. Extraction and Characterization of Pectin from Orange (Citrus sinensis), Lemon (Citrus limon) and Tangerine (Citrus tangerina). Proceeding. American Journal of Physical Sciences , 01, No. 2, pp.17 - 30,

Wachida, N. 2013. Ekstraksi Pectin Dari Kulit Jeruk Manis (Citrus sinensis Osbeck) (Kajian Tingkat Kematangan dan Jenis Pengendap). Skripsi. Universitas Brawijaya, Malang.

Wang, W., Feng, Y., Chen, W., Adie, K., Liu, D., \& Yin, Y., 2021. Citrus pectin modified by microfluidization and ultrasonication: Improved emulsifying and encapsulation properties. Ultrasonics - Sonochemistry, 70, pp.105322. DOI: https://doi.org/10.1016/j.ultsonch.2020.105322 
Wang, X., Chen, Q., \&Lu, X, 2014. Pectin Extracted from Apple Pomace and Citrus Peel by Subcritical Water. Food Hydrocolloids, 38, pp. 129-137. DOI: https://doi.org/10.1016/j.foodhyd.2013.12.003

Widiastutik, D.R. 2015. Ekstraksi Pektin Kulit Jeruk Bali Dengan Microwave Assisted Extraction Dan Aplikasinya Sebagai Edible Film. Skripsi. Universitas Negeri Semarang

Wulandari, K., \& Simon, B.W, 2018. Optimasi Proses Ekstraksi Pektin Dari Kulit Dan Jerami Nangka (Artocarpus heterophyillus) (Kajian Rasio Bahan Pengendap dan Lama Pengendapan) Menggunakan Metode Respon Permukaan. Jurnal Pangan dan Agroindustri, 6, pp. 38-48. DOI: https://doi.org/10.21776/ub.jpa.2018.006.04.5

Yadav, S. D., Namrata S. B., Namrata N. W., \& Deepali C. S. 2018. Extraction and Characterization of Petin from Sweet Lime. Procceding. International Conference on Multidisiplinary Research \& Practice 4:58-63.

Yanhua, L., Xinwei, H., Yuecheng, M., Fan, Z., Zhipeng, S. \& Ling, H., 2018. Effect of the modified high methoxyl pectin on the stability of the fermented milk beverage. International Journal of Food Properties, 21, pp. 2075-2086. DOI: https://doi.org/10.1080/10942912.2018.1485029

Zanella, K., \& Taranto, O. P., 2015. Influence of the drying operating conditions on the chemical characteristics of the citric acid extracted pectins from 'pera' sweet orange (Citrus sinensis L. Osbeck) albedo and flavedo. Journal of Food Engineering, $166, \quad$ pp. 111-118. http://dx.doi.org/10.1016/j.jfoodeng.2015.05.033 